\title{
Food history and gastronomic traditions of beans in Italy
}

\author{
Giandomenico Corrado* (1)
}

\begin{abstract}
Beans have been regarded primarily as a staple food for peasants, an affordable protein source for the mass, and a symbol of rustic simplicity by writers of all ages. Among legumes, the common bean (Phaseolus vulgaris L.) probably plays the leading role in typifying these attributes. This species has also shown a remarkable ability to spread around the globe and to replace similar local species in virtually all the cuisines of the world, being nowadays embodied in the gastronomy of several countries. Attitudes toward beans are changing recently, and this legume is no longer considered as only the meat of the poor. This review aims to present a critical overview of the history and role in the gastronomy of common bean and other main cultivated legumes in Italy. After presenting the origin of common bean and its name, and the impact of its introduction to Europe, this contribution discusses the gastronomic history of beans in Italy and the role that socio-cultural differences have played in shaping the use of beans, the conservation of landraces, and food diversity. Finally, perspectives are discussed considering the recent trends in gastronomy and food tourism.
\end{abstract}

Keywords: Common bean, Phaseolus vulgaris, Landraces, Food, Culinary traditions

"Beans, on the contrary, produce urine and are fattening, two very good things. But they induce bad dreams."

Severinus the herbalist

\section{(The name of the rose, Umberto Eco)}

\section{The origin of the name in the Western culture and of the common bean}

The cultivation of legumes goes back to the Neolithic Age and the dawn of agriculture [1]. Beans likely became an integral part of the human diet with the development of agricultural techniques such as irrigation and companion planting, considering the indeterminate climbing growth habit of the species. Beans are already cited in the Old Testament of the Holy Bible (cf. Ezekiel, 4,9). However,

*Correspondence: giacorra@unina.it

Department of Agricultural Sciences, Federico II University of Naples, Naples, Italy the word "bean" has been used liberally, without a specific botanical connotation, as is still the case today. For example, in the epic poem Iliad [2], the oldest surviving work of Greek literature, the "dark fava beans" (кú $\alpha \mu \circ$ $\mu \varepsilon \lambda \alpha v$ óxровৎ) have been translated sometimes as "dark (common) bean." Beans are described in ancient Greek under the name of dolichos (e.g., by Theophrastus, the father of botany) and fasiolos (e.g., by Dioscorides). The corresponding Latin words are faseolis (cf. Caelius Apicius, De Re Coquinaria 8.6.1.2) and phaselus/faselus (cf. Publius Vergilius Maro, Georgica 1.227; L. Iunius Moderatus Columella, De Re Rustica 2.7.1.2, 2.10.4.3, 2.10.4.8, 10.1.1.377, and 11.2.75.5). Due to the similarity of the name, the bean was also considered to have been introduced to Rome from the Greek-Roman city of Phaselis, in ancient Lycia, hence the name for the genus [3]. It has been also proposed that the word phaselus comes from the ancient Greek phaselus ( $\phi \alpha \sigma o ́ \lambda \iota$ in modern Greek), a light sailing boat with a bean-shaped hull [4]. Phaselus is also often used in Latin to indicate a yacht [5]. Nonetheless, is also conceivable that beans were likely known 
by the Greek civilization well before the development of that kind of vessel. The species name derives from the fact that beans have been always considered an ordinary and plebeian food, hence "vulgaris" (of the mass) [6]. The Roman historian Suetonius, to underline the avarice of the emperor Galba, reports that he rewarded his zealous and diligent accountant with a dish of legumes (cf. Gaius Suetonius Tranquillus, De Vita Caesarum, Gal.12.3.4). The words legume and pulse have Latin roots too. The former derives from the verb leggo meaning to collect, to seize, but also to extract, to remove. Leguminibus (plural of legumen) were probably all sorts of grains in pods whose seeds are collected inside them. The word pulse has an interesting origin, coming from the ancient Roman dish puls. The puls is obtained by mixing the flour of some cereals with hot water, milk (when available), and other ingredients such as wine, pig's fat and fagots, crushed pepper, and salt, to give a final product like an emmer porridge [7]. It was also common, for instance for legionaries, to add legumes (as a complementary source of essential amino acids) and seasonal vegetables to $\mathrm{puls}$ [8].

In Mexico, archaeological studies have traced the origin of common bean (Phaseolus vulgaris L.) to more than 7,000 years ago $[9,10]$. Archaeological remains do not show evidence of wild beans, suggesting that bean cultivation was already well established and diffused in several parts of the American continent. The American continent is considered the center where wild common bean originated and spread. Nonetheless, the precise location of the center of origin is still debated. It is currently believed that the domestication of common bean independently occurred in Mexico and Southern Andes nearly 8000 years ago $[11,12]$.

Common beans were diffused in North, Central, and South America in the Pre-Columbian era. It is well documented that the "Three Sisters" (winter squash, maize, and bean) were at the core of the cropping systems of many Native American agricultural tribes [13]. The beans provide nitrogen compounds to the other plants by fixing nitrogen, the corn provides stalks for the climbing bean, and the squash a protective shelter to keep the soil moist and to contain weeds. At the time of the discovery of the Americas, Aztec agriculture was technically advanced (e.g., terraced farming, irrigation systems, chinampas, etc.) and the cuisine was largely based on maize and common bean. Early explorers such as Columbus and Verrazzano mentioned beans (red and white) and the importance of pulse crops for local populations [14]. Based on the Codex Mendoza, it has been estimated that Montezuma received 5000 tons of beans per year as tribute, an indirect evidence of the large diffusion and centrality of this cultivation [15].

\section{Legumes before the introduction of the common bean in Europe}

Common bean is an introduced crop for Europeans and the "traditional bean" in Italy, as well as in many Mediterranean countries, was the cowpea (Vigna unguiculata L. Walp) [16]. This species was formerly classified under the genus Dolichos. The distinctive trait of the cowpea seeds is the presence of a dark spot circling the hilum, which originated both the common name black-eyed pea and the old botanical name D. melanophtalmus DC. Cowpea was probably domesticated in West Africa [17].

Most of the information on beans in Italy in ancient times comes from the Greco-Roman world. Regardless of local diversity, the relatively uniform geo-morphological and climatic features of the Mediterranean basin determined the emergence, especially along the coasts, of settlements and cultures with similar primary productions. Specifically, the Aegean area (i.e., the Greek peninsula, the Aegean islands, and the Anatolian coasts) on one side, and the Tyrrhenian-Ionian one (the Magna Graecia) on the other, constitute a sufficiently uniform cultural area to allow a unitary treatment. Literature and scholarly writing indicated that the legumes cultivated in these areas were chickpeas (Cicer arietinumI L.), fava beans (Vicia faba L.), lentils (Lens culinaris Medikus), peas (Pisum sativum L.), lupins (Lupin spp.), as well as Vigna unguicolata (see for instance L. Iunius Moderatus Columella, De Re Rustica 2.7.1.2). The cowpea was certainly present in Italy since the Greco-Roman times [18] as also evidenced in the "De re coquinaria" [19]. Chickpeas and fava beans could be grown not only in horti but also in open fields, given their very wide use. In Italy, these legumes could be worked with bovine towed plowing [20]. For lower classes and small farms, horticulture was as important if not more important than cereal growing. A 1/2-hectare plot could not provide enough resources for a plowing animal and legumes were therefore a key resource of proteins and calories, essential to complement cereals in a mostly vegetarian diet. Moreover, legumes, as many other horticultural products, did not require processing, such as threshing and grinding for cereals, or pressing and milling for olive oil. A difference between Classic Greek and Imperial Rome was that in Attica, vegetable gardens were confined to the suburban area by the availability of freshwater for irrigation, while around Rome, starting from the first century AD, a fruit and vegetable "belt" consisting of small plots of about one hectare surrounded the Eternal City for a radius of few kilometers [20]. The fall of the Roman Empire coincided with a reduction, if not the end, of imports of exotic foods, such as palm date and pepper, yet a wealth of cereals and legumes (e.g., field bean, lentils, grass peas) indicated the predominant role of these plants in the diet of 
peasants [21]. In Italy, the fava bean was the most important legume until the Renaissance. The main reasons were the ability to grow without stacks or support and its adaptability to a colder climate. The fava bean is generally eaten raw, although one of the most difficult to digest, and therefore was also employed as a source of proteins for horses. In the Middle Ages, legumes were an integral part of the cultivation order, and they were promoted to the rank of small-grain cereals. For instance, the word grains include both cereals and legumes in deeds and contracts. Fava bean had a dominant role in Italy, often being separated or explicitly mentioned in the polyptychs (polittici) and other documents of the early Middle Ages [22]. The reason should not be sought only in the food value of the seeds, but also in the agronomic value that the plant, especially regarding the possibility of autumn sowing and the beneficial effect for soil fertility in a graincentered agriculture.

\section{First evidence of the common bean in Italy}

After the discovery of the Americas, common beans became in a relatively short time a staple food, if compared to other introduced crops such as maize, tomato, potato, and peppers [23]. The first mentions of the introduction of common beans from the Americas are anecdotal. They refer to a donation of seeds from Charles V, the Holy Roman Emperor, to Pope Clemente VII, born Giulio di Giuliano de' Medici [24]. More likely, the introduction of common beans from the Americas might have been largely unrecorded, with multiple introductions during time [25]. This is because Europeans recognized the common bean as a new type of bean, while potato and tomato were considered exotic species. These were later introduced into the local gastronomy because similar to other domestic toxic Solanaceae. Therefore, even after Columbus voyages, the word "bean" may indicate Phaseolus spp. and Vigna/Dolichos spp. The study of paintings and images in cookbooks and naturalist books has been always considered useful also to examine social customs and food habits. The Italian painting "Il Mangiafagioli" (The Bean Eater, 1584-1585) by Annibale Carracci most likely shows a dish with black-eyed peas. On the other hand, the decoration of the Loggia of Villa Farnesina in Rome (1519) by Giovanni da Udine, depicts around 200 botanical species, and includes domestic and introduced crops, such as the Three Sisters, and almost certainly common bean. This is easily discernable from the broad beans in the frescoes. This artwork should be therefore considered the first European depiction of common bean [26]. The Italian botanist Pietro Mattioli (Matthiolus, 1501-1578) wrote that beans were common throughout Italy and that they presented different colors (red, yellow, white) and seed patterns (speckled) [27]. This variability has been considered indirect proof of the exotic origin of the plant material. However, a similar variability in color and size was also mentioned by Ibn al-Áwwam, the Arab agronomist of the twelfth century [28]. Naturalists' accounts also suffer from the fact that the word "bean" has not always been accompanied by a precise morphological description or illustration that allows distinguishing what is now known as $P$. vulgaris from other species of the same or different genera. For instance, some naturalists also attributed some beans to Smilax hortensis. This species (lo Smilace de' gli orti) was described into the "Dioscoride" by the Mattioli as producing the socalled fagioli turcheschi (an archaic adjective that can be translated as "with many colors" or "colorful") [29], and by the German botanist Fuchs (Fuchsius, 1501-1566) as producing the "fagiouli italiani" (the Italian beans) [3]. It is believed that Fuchs left the first depiction of common bean in a European herbal [25]. However, he does not mention its possible overseas origin or the word phaseolus. Although these botanists lived in the XVI century, it is not certain that they specifically refer to $P$. vulgaris, while Mattioli identifies other introduced crops, such as tomato and pepper. At that time, it was known that some beans could have been "recently introduced," such as the "fagiuolo di Spagna" (classified at that time as P. multiflorus) [3]. Similarly, indications of the type of beans are missing also in cookbooks [30-32]. The Middle East/ Asian origin of the common bean (P. vulgaris) was formally questioned starting from the nineteenth century. Following the discovery of vessels containing common beans in Peruvian tombs of Ancón, in 1883 the Swiss botanist de Candolle correctly proposed that common bean (P. vulgaris) originates from the Americas, with the Euro(Afro)-Asiatic beans belonging to Dolichos (currently, Vigna) genus [33].

\section{The diffusion of common bean after the Columbian exchange and impact on the culinary use of beans}

The transfer of common bean from the Americas to Europe was in all probability associated with a genetic bottleneck, which reduced the diversity of the European bean because of founder effect [34]. However, since its introduction in the Old Continent, common bean has experienced rapid diversification into a multitude of new varieties. It has been suggested that Europe, most notably the South-Western area, can be regarded as a secondary diversification center for $P$. vulgaris [35], with variants that have not been documented in the Americas [36]. The factors that contribute to this adaptive radiation include the new environmental conditions, the different farming techniques (such as new rotations and planting time), and the multiple uses of the plants. Specifically, according to the stage of maturity, beans are grown to produce green 
or snap beans (consumed as fresh or processed pods), green shell or fresh beans (full-sized seeds consumed as fresh), dry or dry shell beans (full-size seeds, dried and consumed only after processing). Additionally, green beans can be harvested at different stages and can come in different sizes, from the small cylindrical pods available globally in frozen bags or canned, to the larger flattened and tender green beans with a fibrous suture that is removed before cooking, sold fresh in local markets in Southern Italy and Greece. The green beans have always been popular in Italy, and it was common in the warmest area of Southern Italy to sow them in autumn, to harvest the pods before Christmas. It is probably no coincidence that Italian cookbooks more often refer to green beans for Phaseolus spp. [23], probably because many archeochefs also aimed to highlight the possible consequences for health of the various ingredients. Under this perspective, dry beans have always been considered one of the toughest to digest and gassier legumes [30].

Before the Columbian exchange, the scarlet runner bean (P. coccineus L.) and the Lima bean (P. lunatus L.) were the species belonging to the genus Phaseolus that were used to produce fagioli in Italy. Today, only very few varieties of $P$. coccineus are cultivated [37], typically in hillsides and mountainous areas in Central and Northern Italy, usually 400-500 m a.s.l. Cowpea has virtually disappeared in Italy. It has been quickly displaced by Phaseolus spp. soon after their introduction in Europe, because of higher yield with similar agronomic practices. In some areas of the Campania region, Vigna unguiculata had the folk name of "fagiolo comune" (common bean) [16], an indication of its past diffusion. Already in the'80, cowpea cultivation in the Campania, Apulia, and Basilicata regions was limited to family gardens, mainly for domestic consumption of green pods [16]. Cowpea almost completely disappeared, being mainly present, on limited acreage, in some areas of the Campania (e.g., Sele Valley and Alburni mountain range) and Apulia regions [38]. Lupins are perhaps mostly known because of the tragic business venture described in the "Malavoglia," the best-known novel by Giovanni Verga [39]. In Italy, they are almost exclusively sold pickled in brine, as a takeaway snack in street markets and village fairs. Lupins are, therefore, the main and probably, the only contemporary expression of street food related to legumes in Italy.

\section{Diversity of common bean and the development of landraces}

The variety of climate systems in Italy and the local selection applied by farmers generated many bean landraces. This is also due to the small acreages dedicated to this plant species, usually present in remote, relatively isolated rural villages or islands [40, 41]. The Italian bean germplasm is characterized by a high morphological and genetic diversity. The first systematic classification of the Phasulus vulgaris races in Italy is probably in the "Flora Napolitana" by Michele Tenore, founder and director of the "Real Orto Botanico" of Naples [42]. A larger systematic description was later performed by Orazio Comes, the Director of the "Istituto Superiore Agrario di Portici" (Naples) [3]. In his work, thousands of local, national, and international $P$. vulgaris races were classified into 472 groups, primarily according to the seed shape (compressus = kidney shape; oblungus; ellipticus; sphaericus), color pattern (from uniform to variegated) and color, which presented a remarkable variability. Comes also discussed that many cultivated races could be the result of hybridization and that "races are local, and therefore they maintain their traits with adequate stability only in the environment in which they are produced" [3]. In Southern Italy, common bean is probably the horticultural crop with the highest number of landraces [43, 44]. Different works based on morphological and DNA-based analyses have illustrated the large diversity and availability of common bean landraces in regions of Central and Southern Italy, such as Lazio [45], Abruzzo [46], Campania [47], Basilicata [48], Apulia [49], Calabria [50], and Sicily [41] (Fig. 1). Currently, many landraces appear severely endangered and at risk of extinction due to the advanced age of the farmers, the abandonment of small labor-intensive family farms, and the migratory pattern of peoples from rural villages.

\section{Gastronomic history of beans in Italy}

Legumes are the main protein source of the Mediterranean diet [51]. Since Greco-Roman times, beans were widely consumed especially by the lower classes. Convincing evidence of the popular use of beans during Roman times comes from the Pompeii excavation. Beans and onions were the last suppers of brothel's workers [3]. The popularity of beans in Southern Italy is related also to the ample presence of the so-called agrotowns (large villages in a rural environment where most workers are employed seasonally) [52] and more generally, by the presence of an agricultural-based society in which the cultivated land was owned and managed by noblemen [53]. The Medieval society was highly stratified, and the fresh game was almost exclusively reserved for powerful and well-differentiated social groups. In the Middle Ages, wheat-cantered agriculture was dominant in Italy. Regarding the cultivated species, cereal growing in Southern Italy is aligned with the classical tradition based on wheat, for human consumption, and barley, mainly for animals, in contrast to a more widespread wheat-rye-oats cultivation in the continent [54]. Bread, salt pork, and beans were the 


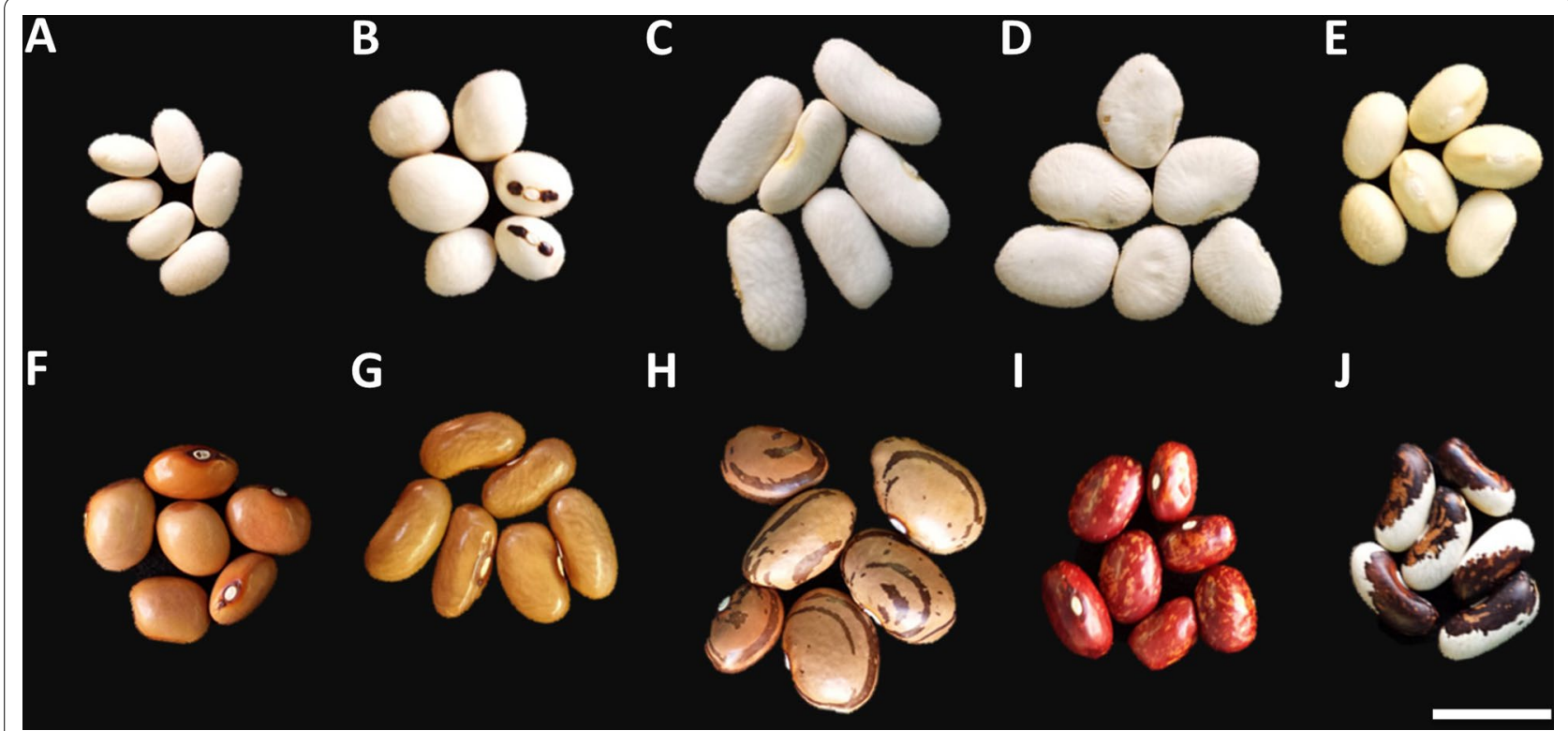

Fig. 1 An example of the range of morphological diversity of the common been seeds in the landraces of the Campania region in terms of seed size, color and pattern. A: "Tondino bianco"; B: "Occhio Nero"; C: "Dente di morto"; D: "a formella"; E: "Zolfariello"; F: "della Regina (piccolo)"; G: "Screziato"; H: "della Regina"; J:"Mustaciello." Scale bar: $1 \mathrm{~cm}$

core of the peasants and workers meals [55]. Legumes remained an important source of protein in Southern Italy also because bovines were mainly used as work animals and less diffused compared to Northern Italy, mainly due to the need for pastures and adequate rainfall. Starting from the Late Middle Ages, wheat increasingly assumed the role of the central element in the Italian diet in the form of bread, while small-seeded cereals and legumes had a complementary role. As also other civilizations, Romans were making bread including fava bean flour as well as different cereals, such as foxtail millet [56]. This custom was common until the Middle Ages, yielding a dark colored bread, heavy to digest and with a bitter taste, mainly because of the use of legumes [57]. In Italy, since the eighth century, there is evidence of pulmentaria, dishes of a very variable recipe that can be considered similar to polenta. Pulmentaria are made with fava beans as the main ingredient, roughly or finely crushed to flour [58]. Even after the transformations affecting the human diet after the fall of the Western Roman Empire, the fava bean remained the most important legume in virtually all Italian regions [59]. Other legumes, such as vetches and grass pea, assumed importance depending on the areas. For example, in Northern Italy, the use of broad beans for human consumption gradually decreased with the diffusion of maize [60]. The decline of dried broad beans in Southern Italy was therefore much more limited. In the eighteenth century, while maize and rice continued to be more popular in Northern Italy, durum wheat pasta became the central food in Southern Italy, first in urban areas and then in rural settings [61]. This area remained characterized by the wide consumption of vegetable soups made mainly of salty dry bread, common or broad beans, and bulbous plants (onion and/or garlic) [62]. The invention of canning in the nineteenth century, revolutionized the use of common bean in the Western world, making it quick to prepare and convenient to store [23]. However, canning beans had limited importance in Italy and especially in the rural area of the South, where both the warmer and drier climate and the presence of a wealth of local varieties did not create a strong demand for canned beans. In Southern Italy, the food industry was mostly motivated by processing fresh, easily perishable tomatoes, such as the "San Marzano." After the Italian Unification in the nineteenth century, the lack of effective agrarian reforms, heavy taxes, and other economic measures implemented to boost northern industry (e.g., rail and heavy industry) were the main reasons for an economic crisis that associated with large-scale migration and abandonment of rural territories and traditions in Southern Italy [63, 64]. During the fascist regime, common beans gained importance due to the progressive diplomatic isolation of Italy. Fascist food policies were based on self-sufficiency (autarchia) and alimentary sovereignty [65]. The ideal Italian diet was with little animal proteins and based on carbohydrates 
(pasta and bread) supplemented with legumes, available vegetables, olive oil, fresh fruit (mainly citrus), and wine. However, the nutrition levels remained substandard both as calorie and protein intake for much of the lower class, and in the later period of the fascist regime, also for the middle and upper classes [66]. Potatoes, common bean and (savoy) cabbage represented the main subsistence cultivations for autumn-winter seasons. During the Second World War, the availability of meat proteins strongly diminished and oral tradition indicates that in the rural population of Southern Italy, the imperishable, everlasting dry beans were carefully stored (e.g., buried in pots underneath the soil) as insurance against even harder times.

After WWII, the cultivated area of $P$. vulgaris peaked during the'50 and then, severely declined (Fig. 2). Dry beans represented almost $3 / 4$ of the area dedicated to legumes [67]. The sharpest reduction in the cultivation occurred during the so-called Miracolo Italiano (the Italian economic boom of the'60) when a significant part of the Italian population experienced a shift from a rural society to an urban, modern industrial society with more heterogeneous and less traditional cultural habits $[68,69]$. Since 1989, the area cultivated for green beans

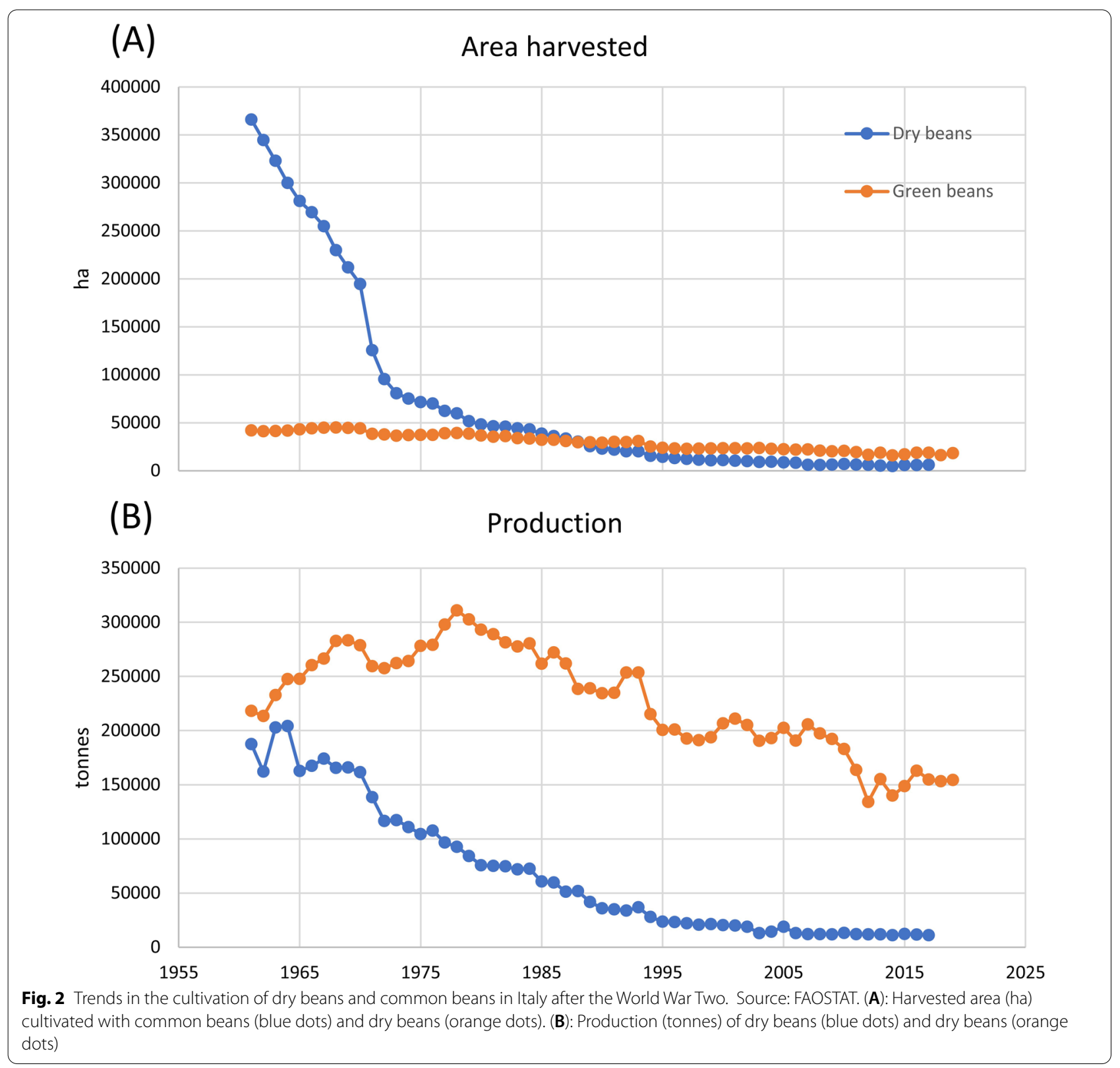


exceeded the one for dry beans. Green beans are mainly cultivated for their industrial transformation. Nowadays, the Italian production of common beans is too heterogeneous in terms of germplasm and supply to meet the technological requirements of the food processing industry. While landraces have a high value to preserve genetic variability and possibly organoleptic qualities, the local production cannot currently suit the demand of the food industry. Moreover, Italy lacks highly specialized production areas that can benefit a canning industry.

\section{Status and perspectives of the common bean in Italy}

According to Food and Agricultural Organization (FAO), Phaseolus vulgaris is the most important edible legume for direct consumption in the world (http://www.fao.org/ faostat/en/, accessed May 2021). The cultivation is distributed in the five continents and the most widespread varieties include black beans, white beans, pinto beans, and kidney beans. In Italy, professional pulse farming currently involves faba bean, common bean, and pea. Lupin, chickpea, and lentil almost disappeared from cultivation and are found mainly in small farms. Common bean cultivation has lost competitiveness in Italy and many EU countries mainly due to a decreasing price in the international market and to the larger availability of animal proteins [70]. Bean consumption is strongly identified with a rural diet, even though $P$. vulgaris was probably consumed by wealthy people as an alternative to the more popular beans when introduced in Europe. Moreover, the evolution of high-input cropping systems (e.g., diffusion of fertilizers, monoculture, and mechanical harvesting) limited the importance of legumes as nitrogen fixers in crop rotation or companion planting. The need for uniformity is associated with the displacement of landraces with the highly uniform and stable contemporary varieties. Landraces have not bred to introgress resistance genes that are normally present in contemporary cultivars [71]. However, in different European countries such as Italy, Greece and Spain, common bean landraces still appear in fields especially for their strong link with rural gastronomy. In Italy, common bean landraces are associated with niche products in local markets, or amateur farming [37, 47]. They are receiving attention because of the consumers' perception of authentic food of higher quality. Traditional agricultural products have a prominent role in supporting social, historical, and cultural identity and are becoming increasingly attractive [72]. For instance, efforts to improve the economic and environmental sustainability of both tourism and agriculture in rural areas exploit local food [73, 74]. A good proportion of food festivals in Southern Italy are based on common beans landraces [75], such as those with a PDO or PGI label [37]. In addition, there has been a worldwide increased appreciation of the heart-healthy Mediterranean diet and more generally, larger attention to healthy eating, factors that have led to the rediscovery of legumes as a protein source [76]. These trends increase the possibility that local common beans will be of wider interest in Italy as well as in other high-income countries.

\section{Conclusion}

Beans, and more generally legumes, have been cultivated and eaten as an emblem of rustic simplicity. The consumption of common beans cannot be realistically expanded to a level that can shift current agricultural trends in Italy, which is now a heavy importer (approx. $90 \%$ of the total market), considering the globalization of the food offer and industry. Interest in local landraces is steadily growing, and this phenomenon relies on their cultural value. The popularity of specific landraces is linked to specific geographic areas and names, being strongly connected with the rising gastronomy tourism [77]. It is bizarre that today common bean landraces sell for a premium price and are valued by gastronomists, critics, food-bloggers, and alike. Nonetheless, the adoption of a culinary element that typifies a rustic identity for those who struggled to put food on the table appears today a hidden gastronomic snobbery. The humble beans should be appreciated in a wider gastronomic and nutritional framework. Their long-term promotion cannot be limited to the idea of novelty and it should also include a less ostentatious approach to cooking [78], a recognition of a national gastronomic identity, and a dietary appreciation that goes beyond the meat protein rivalry.

\section{Acknowledgements}

Not applicable.

\section{Authors' contributions}

The author read and approved the final manuscript.

\section{Funding}

This research received no specific grant from any funding agency in the public, commercial, or not-for-profit sectors.

Availability of data and materials Not applicable.

\section{Declarations}

Ethics approval and consent to participate Not applicable.

\section{Consent for publication}

Not applicable.

\section{Competing interests}

The author declares that there are no competing financial interests or personal relationships that could have appeared to influence the work reported in this paper. 
Received: 30 July 2021 Accepted: 8 February 2022

Published online: 21 February 2022

\section{References}

1. Kislev ME, Bar-Yosef O. The legumes: the earliest domesticated plants in the Near East? Curr Anthropol. 1988;29(1):175-9.

2. Homer. The Illiad: Penguin; 1998.

3. Comes O. Del Fagiuolo comune ("Phaseolus vulgaris" L.), storia, filogenesi, qualità e sospettata sua tossicità ; sistemazione botanica. Napoli (Italy): Cooperativa tipografica; 1909.

4. Quattrocchi U.CRC world dictionary of medicinal and poisonous plants: common names, scientific names, eponyms, synonyms, and etymology (5 Volume Set): CRC press; 2012

5. Cignolo C. Terentiani Mauri De Litteris, De syllabis, De metris. Hildesheim (Germany): Olms-Weidman; 2002.

6. Volk K. Vergil's Georgics: OUP Oxford; 2008

7. Alcock JP. Around the Table of the Romans: food and feasting in Ancient Rome. Gastronomica. 2004:4(1):103.

8. Merrow A. Caesar's Great Success: Sustaining the Roman Army on Campaign: Frontline Books; 2020

9. Piperno DR, Smith BD. The origins of food production in Mesoamerica. Oxford: The Oxford Handbook of Mesoamerican Archaeology Oxford University Press; 2012. p. 151-64

10. Watling J, Shock MP, Mongeló GZ, Almeida FO, Kater T, De Oliveira PE, Neves EG. Direct archaeological evidence for Southwestern Amazonia as an early plant domestication and food production centre. PLOS ONE 2018:13(7):e0199868.

11. Bitocchi E, Nanni L, Bellucci E, Rossi M, Giardini A, Zeuli PS, Logozzo G, Stougaard J, McClean P, Attene G. Mesoamerican origin of the common bean (Phaseolus vulgaris L.) is revealed by sequence data. Proceedings of the National Academy of Sciences 2012:109(14):E788-E796.

12. Schmutz J, McClean PE, Mamidi S, Wu GA, Cannon SB, Grimwood J, Jenkins J, Shu S, Song Q, Chavarro C. A reference genome for common bean and genome-wide analysis of dual domestications. Nat Genet. 2014;46(7):707-13.

13. Ngapo TM, Bilodeau P, Arcand Y, Charles MT, Diederichsen A, Germain I, Liu Q, MacKinnon S, Messiga AJ, Mondor M. Historical indigenous food preparation using produce of the three sisters intercropping system. Foods. 2021;10(3):524

14. Aykroyd W, Doughty J. Legumes in human nutrition., vol. 20. Rome (Italy): Food and Agriculture Organization; 1982

15. de Rojas JL. Storage and Administration in the Aztec Empire. In: Storage in Ancient Complex Societies: Administration, Organization, and Control. Edited by Manzanilla LR, Rothman M. Milton Park (UK): Taylor \& Francis; 2016: 350 .

16. Padulosi S, Ng N. Origin, taxonomy, and morphology of Vigna unguiculata (L.) Walp. Advances in cowpea research 1997:1-12.

17. Huynh BL, Close TJ, Roberts PA, Hu Z, Wanamaker S, Lucas MR,

Chiulele R, Cissé N, David A, Hearne S. Gene pools and the genetic architecture of domesticated cowpea. The plant genome 2013:6(3):plantgenome2013.2003.0005.

18. Corte FD. Plinii naturalis historia: Libri I-VII: Giardini; 1984.

19. Apicius MG, Marsili A. De Re Coquinaria: Edizione Critica Lat. \& Ital; 1957.

20. Longo O. Agricoltura nell'antica Grecia. Rivista di Storia dell'Agricoltura anno. 2003:2:1-17.

21. Brogiolo GP. S. Giulia di Brescia: gli scavi dal 1980 al 1992. Reperti preromani, romani e alto medievali. Sesto Fiorentino (Italy): All'insegna del giglio; 1999

22. Montanari M. Cereali e legumi nell'Alto Medioevo: Italia del Nord, secoli IX-X. Rivista Storica Italiana 1975:LXXXV|I(3):439-492.

23. Albala K. Beans: A History. New York (USA): Bloomsbury Publishing; 2007.

24. Lioi L, Piergiovanni AR. European common bean. In: Genetic and genomic resources of grain legume improvement. Elsevier; 2013: 11-40.

25. Zeven $\mathrm{A}$. The introduction of the common bean (Phaseolus vulgaris $\mathrm{L}$.) into Western Europe and the phenotypic variation of dry beans collected in the Netherlands in 1946. Euphytica 1997:94(3):319-328.

26. Caneva G. II mondo di Cerere nella loggia di Psiche. Rome (Italy): Palombi; 1992
27. Mattioli PA I Discorsi Di M. Pietro And Matthioli Sanese .. Ne I Sei Libri Di Pedacio Dioscoride Anazarbeo Della Materia Medicinale (etc.): Valgrisi; 1563.

28. al-Áwwam YMI, Muhammad YB. Libro de Agricultura. Valladolid (Spain): Editorial Maxtor; 1878

29. Mattioli PA. II Dioscoride: Roffinello; 1549

30. Pisanelli B. Trattato della natura de'cibi, e del bere: Biblioteca Pubblica Bavarese; 1782

31. Gaudentio F, Gianni G. Il panunto toscano. Sal Bolognese (Italy): Arnaldo Forni; 1990.

32. Corrado V. II cuoco galante. Napoli (Italy): N. Russo; 1793.

33. de Candolle A. The origin of cultivated plants. Cambridge (UK): Cambridge University Press; 2011.

34. Gepts P. Origin and evolution of common bean: past events and recent trends. HortScience. 1998;33(7):1124-30.

35. Angioi SA, Rau D, Attene G, Nanni L, Bellucci E, Logozzo G, Negri V, Zeuli PS, Papa R. Beans in Europe: origin and structure of the European landraces of Phaseolus vulgaris L. Theor Appl Genet. 2010;121(5):829-43.

36. Santalla M, Rodiño A, De Ron A. Allozyme evidence supporting southwestern Europe as a secondary center of genetic diversity for the common bean. Theor Appl Genet. 2002;104(6):934-44.

37. Piergiovanni AR, Lioi L. Italian common bean landraces: history, genetic diversity and seed quality. Diversity. 2010;2(6):837-62.

38. Lioi L, Morgese A, Cifarelli S, Sonnante G. Germplasm collection, genetic diversity and on-farm conservation of cowpea [Vigna unguiculata (L.) Walp.] landraces from Apulia region (southern Italy). Genetic Resources and Crop Evolution 2019:66(1):165-175.

39. Tanga MI. I Malavoglia a tavola. Giovanni Verga e la cucina dei contadin siciliani: Il Leone Verde; 2008.

40. Sicard D, Nanni L, Porfiri O, Bulfon D, Papa R. Genetic diversity of Phaseolus vulgaris L. and P. coccineus L. landraces in central Italy. Plant Breed 2005; 124(5):464-472

41. Lioi L, Nuzzi A, Campion B, Piergiovanni AR. Assessment of genetic variation in common bean (Phaseolus vulgaris L.) from Nebrodi mountains (Sicily, Italy). Genet Resour Crop Evolut 2012;59(3):455-464.

42. Tenore M. Flora napolitana, ossia Descrizione delle piante indigene del Regno di Napoli e delle più rare specie di piante esotiche coltivate ne' giardini, del cavalier Michele Tenore dottore in medicina, professore di botanica: Stamperia Reale; 1811

43. Perrino P, Hammer K, Hanelt P. Collection of land-races of cultivated plants in South Italy 1983. Die Kulturpflanze. 1984;32(2):207-16.

44. Hammer K, Laghetti G, Perrino P. Collection of plant genetic resources in South Italy, 1988. Die Kulturpflanze. 1989;37(2):401-14.

45. Piergiovanni AR, Taranto G, Losavio FP, Pignone D. Common bean (Phaseolus vulgaris L.) landraces from Abruzzo and Lazio regions (Central Italy). Genet Resour Crop Evol 2006;53(2):313-322

46. Piergiovanni AR, Taranto G, Pignone D. Diversity among common bean populations from the Abruzzo region (central Italy): a preliminary inquiry. Genet Resour Crop Evol. 2000:47(5):467-70.

47. Scarano D, Rubio F, Ruiz JJ, Rao R, Corrado G. Morphological and genetic diversity among and within common bean (Phaseolus vulgaris L.) landraces from the Campania region (Southern Italy). Scientia Horticulturae 2014;180:72-78.

48. Limongelli G, Laghetti G, Perrino P, Piergiovanni AR. Variation of seed storage proteins in landraces of common bean (Phaseolus vulgaris L.) from Basilicata, Southern Italy. Euphytica 1995;92(3):393-399.

49. Piergiovanni AR, Procino G, Cifarelli S, Lioi L. Monti Dauni district (Apulia region, southern Italy): an environment promoting on farm conservation of common bean (Phaseolus vulgaris L.) landraces. Genet Resour Crop Evol 2019:66(7):1459-1468.

50. Mercati F, Leone M, Lupini A, Sorgona A, Bacchi M, Abenavoli MR, Sunseri F. Genetic diversity and population structure of a common bean (PhaseoIus vulgaris L.) collection from Calabria (Italy). Genetic Resour Crop Evol 2013:60(3):839-852.

51. Willett WC, Sacks F, Trichopoulou A, Drescher G, Ferro-Luzzi A, Helsing E, Trichopoulos D. Mediterranean diet pyramid: a cultural model for healthy eating. Am J Clin Nutr. 1995;61(6):1402S-1406S.

52. Curtis DR. Coping with crisis: the resilience and vulnerability of preindustrial settlements. London: Routledge; 2016.

53. Blok A. South Italian agro-towns. Comp Stud Soc Hist. 1969:11(2):121-35. 
54. Montanari M. Campagne medievali. Strutture produttive, rapporti di lavoro, sistemi alimentari: Einaudi; 1984.

55. Musca G Uomo e ambiente nel Mezzogiorno normanno-svevo. In: Ottave Giornate Normanno-Sveve: 1989; Bari. Dedalo: 368

56. Baldini L. Utilizzazione e coltivazione della fava (Vicia faba L.) in Italia dall' epoca romana al tardo medioevo. Rivista di storia dell'agricoltura 1992;32(2):157-173.

57. Manetti S. Delle specie diverse di frumento e di pane siccome della panizzazione memoria del dottor Saverio Manetti pubblicata sotto gli auspici dell'illustriss. sig. Andrea Ginori patrizio fiorentino provveditore del Tribunale e Magistrato della Sanità, e dell'Arte del Cambio di questa città, e attualmente presidente dell'Imperial Società Fisico-Botanica fiorentina: nella stamperia Moücke; 1765.

58. Montanari M. Alimentazione e cultura nel Medioevo: Laterza; 2019.

59. Castrorao Barba A, Speciale C, Miccichè R, Pisciotta F, Aleo Nero C, Marino P, Bazan G. The Sicilian Countryside in the Early Middle Ages: HumanEnvironment Interactions at Contrada Castro. Environmental Archaeology 2021:1-16.

60. Messedaglia L. Agricoltura e alimentazione dei contadini: storie vecchie e fatti nuovi : discorso letto il 27 giugno 1926 nell'adunanza solenne del Reale Istituto Veneto di Scienze, lettere ed arti dal m. e. Luigi Messedaglia. Venezia (Italy): Premiate Officine Grafiche C. Ferrari; 1926.

61. Sereni E. Storia del paesaggio agrario italiano, 20th edn. Roma (Italy): Laterza; 1961.

62. Pécout G, Balzani R. II lungo Risorgimento: la nascita dell'Italia contemporanea (1770-1922): B. Mondadori; 1999.

63. Lumley R, Morris J, Institute IC. The New History of the Italian South: The Mezzogiorno Revisited: University of Exeter Press; 1997.

64. Nitti FS, De Masi D. Napoli e la questione meridionale, 1903-2005: A. Guida; 2004.

65. Helstosky C. Fascist food politics: Mussolini's policy of alimentary sovereignty. J Mod Ital Stud. 2004;9(1):1-26.

66. Cordova F. Il fascismo nel Mezzogiorno: le Calabrie. Soveria Mannelli (Italy): Rubbettino; 2003.

67. Scarascia Mugnozza GT. Italian contribution to plant genetics and breeding. Viterbo (Italy): University of Tuscia Press; 1998.

68. Crainz G. Storia del miracolo italiano. Roma (Italy): Donzelli Editore; 2015.

69. Chironi S, Bacarella S, Altamore L, Columba P, Ingrassia M. Consumption of spices and ethnic contamination in the daily diet of Italians-consumers' preferences and modification of eating habits. J Ethnic Foods. 2021;8(1):6

70. Pachico D. Trends in world common bean production. In: Bean production problems in the tropics. Edited by Howard F, Schwartz MA, Pastor C, vol. 10. Cali-Palmira (Columbia): Centro Internacional de Agricultura Tropical; 1989: 725.

71. Singh SP. Broadening the genetic base of common bean cultivars: a review. Crop Sci. 2001;41(6):1659-75.

72. Pícha K, Navrátil J, Švec R. Preference to local food vs. Preference to "national" and regional food. Journal of Food Products Marketing 2018;24(2):125-145

73. Giampiccoli A, Kalis JH. Tourism, food, and culture: community-based tourism, local food, and community development in M pondoland. Culture, Agric Food Environ. 2012;34(2):101-23.

74. Fontefrancesco MF. Traditional festive food and fragile aspirations of development in Italy: the case of agnolotti pasta. J Ethnic Foods. 2020;7(1):2

75. Piergiovanni AR. Legumes: staple foods used in rituals and festive events of Apulia region (southern Italy). Food, Culture \& Society 2021:1-19.

76. Lemken D, Spiller A, Schulze-Ehlers B. More room for legume-Consumer acceptance of meat substitution with classic, processed and meat-resembling legume products. Appetite 2019;143:104412.

77. Privitera D, Nedelcu A, Nicula V. Gastronomic and food tourism as an economic local resource: Case studies from Romania and Italy. GeoJournal Tour Geosites. 2018;21(1):143-57.

78. Ferguson PP. Accounting for Taste: The Triumph of French Cuisine. Chicago (USA): University of Chicago Press; 2006.

\section{Publisher's Note}

Springer Nature remains neutral with regard to jurisdictional claims in published maps and institutional affiliations.

Ready to submit your research? Choose BMC and benefit from:

- fast, convenient online submission

- thorough peer review by experienced researchers in your field

- rapid publication on acceptance

- support for research data, including large and complex data types

- gold Open Access which fosters wider collaboration and increased citations

- maximum visibility for your research: over $100 \mathrm{M}$ website views per year

At BMC, research is always in progress.

Learn more biomedcentral.com/submissions 